\title{
A "encarnação" do discurso teológico no Brasil Clodovis Boff: teoria, revisão e debate
}

\author{
Orientador: Mario de França Miranda \\ Mestrando: Francys Silvestrini Adao \\ Área de Concentração: Teologia Sistemático-Pastoral \\ Linha de Pesquisa: Fé e Cultura
}

Como compreender a especificidade da vivência da fé cristã no Brasil, um país formado por uma convergência - nem sempre pacífica - de uma variedade de povos, culturas, tradições? Como pensar e dizer a fé a partir deste contexto, lugar concreto onde um projeto secular de unificação nacional deve assumir os desafios de suas origens plurais e mestiças? Como o discurso teológico foi construindo um caminho próprio de compreensão e de alimentação da fé em terras brasileiras, na busca de autenticidade e coerência em relação aos desafios contextuais, ao modo de vida e à expressão da fé deste povo? Para responder a essas perguntas, este estudo volta seu olhar para um debate teológico-metodológico inter pares, provocado e catalisado por Clodovis Boff. Num primeiro momento, estudam-se os pontos centrais da reflexão epistemológica deste autor, destacando suas convicções e suas inflexões. Num segundo momento, examinam-se os principais elementos que estão em jogo no debate teológico recente no Brasil, situando-os numa discussão intraeclesial - em diálogo com textos do magistério católico - e numa dinâmica sociocultural mais ampla - em diálogo com textos da sociologia brasileira contemporânea. Uma hermenêutica da brasilidade, que considera o lugar do barroco na formação social brasileira, amplia os horizontes deste debate, revelando uma dinâmica de "encarnação" que busca gerar, em todo tempo e lugar, Vida em abundância.

Palavras-chave: Teologia brasileira; Método teológico; Teologia da Libertação. 